Received 03.07.2017

Reviewed 13.08.2017

Accepted 24.09.2017

A - study design

B - data collection

C - statistical analysis

D - data interpretation

E - manuscript preparation

F - literature search

\section{Methodology of assessing the relative environmental validity of developing drainage and irrigation on a regional scale}

\author{
Edmund KACA ABCDEF $₫$
}

\begin{abstract}
Warsaw University of Life Sciences - SGGW, Faculty of Civil and Environmental Engineering, Department of Environmental Management, ul. Nowoursynowska 159,02-776 Warszawa, Poland; e-mail: edmund_kaca@sggw.pl
\end{abstract}

For citation: Kaca E. 2017. Methodology of assessing the relative environmental validity of developing drainage and irrigation on a regional scale. Journal of Water and Land Development. No. 35 p. 101-112. DOI: 10.1515/jwld2017-0073.

\begin{abstract}
The topic of the research is a specific feature of the region within a group of regions - the relative environmental validity of developing drainage and irrigation within it; relative, as it refers to the environmental validity of developing drainage and irrigation in regions belonging to a selected group of regions.

The research revolves around the issue of the methodology for assessing (quantifying) the relative environmental validity of developing drainage and irrigation in a region (province). Developing such a methodology and presenting an example of its application is, thus, the aim of this work.

The methodology comprises two parts. The first of them pertains to generic, e.g.: climate, soil-water, hydrological, etc. quantification of the relative environmental validity of developing drainage and irrigation in regions (provinces), while the second - the synthesis of these partial generic validities into one indicator - the relative environmental validity of developing drainage and irrigation in a region (province). When realizing the first part, indicators characterizing the partial validities for developing drainage and irrigation in subregions (districts) are used, whereas in the second - a fragment of the ELECTRE III multi-criteria dialogue method of ordering of variants.

Based on the proposed methodology, the individual provinces of Poland were classified. The classification was carried out based on such generic validities for the development of irrigation as climatic, soil-water, hydrological and environmental-ecological validity. According to this classification, Opolskie Province is characterized by the strongest environmental validity of developing irrigation, whereas Małopolskie Province - the lowest.

Preliminarily analyses confirmed the accuracy and reliability of the proposed methodology for assessing the relative environmental validity of developing drainage and irrigation in the provinces.
\end{abstract}

Key words: AHP method, ELECTRE III method, land reclamation development, ranking of regions

\section{INTRODUCTION}

The development of drainage and irrigation is understood as a process based on an increase in the number/amount of drainage and irrigation devices maintained in working condition, and reconstructed or modernized devices. It is also perceived as the introduction of innovations pertaining to products, processes or structures for the maintenance or use of these devices and their reconstruction/modernization. It also deals with innovations in the field of organization and management to adapt drainage and irrigation to the changing conditions, especially changing agriculture, requirements of the natural environment and society's expectations.

The topic of the research is the specific characteristic of a region in a group of regions which is the relative environmental validity of developing drainage 
and irrigation within it. Relative, as it pertains to the environmental validity of developing drainage and irrigation in regions belonging to a specified group of regions. The group can consist of homogeneous or not homogeneous regions. The first group consists of the regions in which the environmental needs for the development of drainage and irrigation exceed the environmental possibilities or vice versa, in which the environmental possibilities exceed the environmental needs. In the second group, there are mixture of regions. In some of them the environmental needs for the development of drainage and irrigation exceed the environmental possibilities and in the rest of them is opposite situation.

The problem assumed in the research is the issue regarding the methodology of assessing (quantifying) the relative environmental validity of developing drainage and irrigation in a region (province). The purpose of this work is to develop such a methodology and to present an example of its application.

The ability to assess the relative environmental validity of developing drainage and irrigation in regions (provinces) can be of great cognitive and utilitarian significance. Cognitive, as the developed measurement method can be used as a research tool and practical, as it can be dedicated to those developing strategies for the development of regions, including the development of drainage and irrigation. For instance, based on the results of this measurement, attention can be drawn to regions of higher and the highest rational validity of developing drainage and irrigation, as well as regions of low validity. On this basis, the material scope of maintenance works and reconstructions or modernizations of drainage and irrigation devices in the regions can be centrally planned (suggest).

Details regarding the programming and programs for the development of drainage and irrigation in the Polish provinces, using the indicators of relative rational validity of developing drainage and irrigation, were developed and described by the author [KACA 2015a, b].

\section{MATERIALS AND METHODS}

\section{GENERAL APPROACH}

The methodology of the research results from the general methodology of social-economic studies [BABBIE 2008; NoWAK 2007; WĘZIAK-BIAŁOWOLSKA 2011]. The realization of the aim of the work required a conceptual model of the relative validity of developing drainage and irrigation in a region to be developed, the operationalization of this concept and its scaling. The conceptual model of the analysed concept (here: the validity of developing drainage and irrigation) is the presentation, often in a graphic form, of all of its elements and related concepts, possible relationships between these concepts, as well as the possible relationships between the analysed concept and the outside (empirical) world. Operationalization is a process used to create an operative definition of this concept and related concepts, as well as the relationships between them. In other words, it is a process of giving empirical sense to theoretical terms, and especially, it is a measure of selecting for a specified theoretical amount (concept) its observable indicators. By scaling it is understood the choice of a measurement scale of the concept and its calibration in order to make the measurements reliable and accurate. In the case of survey research, calibration means the selection of items (statements/questions) in the survey and the scale of answers to these questions.

Numerical data contained in the monograph edited by the author [KACA 2014] is used in the work, especially in the presented example. These are data regarding the indicators of the climatic, soil-water, hydrological and natural-ecological validity (need, possibility) of developing drainage and irrigation in districts, developed by ŁABĘDZKI [2014], SZYMCZAK [2014], OSTROWSKI and TUSIŃSKI [2014] as well as by DEMBEK and OŚWIECIMSKA-PIASKO [2014].

\section{CONCEPTUALIZATION \\ AND OPERATIONALIZATION OF RELATIVE ENVIRONMENTAL VALIDITY OF DEVELOPING DRAINAGE AND IRRIGATION}

The environmental validity of developing drainage and irrigation is a characteristic feature of a region, treated in the research as an objectified and quantified view (standpoint, belief) on the issue of the development of drainage and irrigation, often described in development strategies of regions (provinces), especially in regional (provincial) plans (if such exist) for the development of drainage and irrigation. This feature is treated as a theoretical construct - a directly unobservable (hidden) multidimensional variable of the region. A few dimensions of this variable can be distinguished; the most important include the climatic, soil-water, hydrological and environmental-ecological dimensions.

The relative environmental validity of developing drainage and irrigation in a region (province), as an unobservable amount, is indicated by properly selected observable indicators. A single or a few indicators can correspond to each dimension. From a methodological point of view [NOWAK 2007], these are inferential indicators, as their correlation with appropriate dimensions of this variable cannot be confirmed on the basis of direct observation, but are justified in an indirect manner, inferring (deducing) them both from certain observable correlations as well as theoretical assumptions.

A large collection of such indicators can be found in topic-oriented literature. In the research, these will be referred to as primary indicators. Climatic indicators of the validity of developing drainage and irrigation in a region/subregion may include the average totals of precipitation and evapotranspiration for the given period as well as average air temperatures. For 
hydrological indicators - water flows in streams and unitary outflows of water in catchments. Climatic and hydrological indicators developed based on primary indicators regarding the validity of developing drainage and irrigation in regions were interestingly described as early as in the seventies by OSTROMECKI [1971; 1973] and in the eighties by GRABARCZYK [1987]. Attention should be paid to the works of ŁABĘDZKI [2006] regarding agricultural droughts and the works of BAC et al. [1993], in which the agro-climatic regions of Poland are characterized. Water-soil indicators are cited in literature related to soil science. These include works under the scientific editorship of ZAWADZKI [1999] and the work of OKRUSZKO [1976]. The newest works include that of MIODUSZEWSKI [2015], as well as the works of L. Łabędzki, T. Szymczak, J. Ostrowski and E. Tusiński, and also W. Dembek and Z. Oświecimska-Piasko, contained in the monograph edited by the author [KACA (ed.) 2014]. Indicators presented in research are measured in various scales: starting with rating scales (nominal and ordinal), and finishing with quantitative scales (interval and ratio scales), and pertaining to areas the size of a subregion (district). The variety of scales results from the variability of sources from which values of indicators accounted for are derived. The number of indicators pointing to a given dimension of validity also differs.

In the proposed method, the assessment (measurement) of the relative environmental validity of developing drainage and irrigation in regions (provinces) starts with the selection (indexing) and calculation of the values of indicators inferentially connected with the given dimension of validity of developing drainage and irrigation in the subregions (districts) of each region, e.g. climatic, soil-water, hydrological and environmental-ecological validity. Next, based on these values and appropriately prepared ordinal scales, subregions in a given region are appointed to appropriate categories of the given dimension of validity of developing drainage and irrigation. These categorizations serve to develop distributions of the frequency of subregions occurring in a region in individual categories of a given dimension of validity. Based on these distributions, the values of indices of a given dimension of validity of developing drainage and irrigation in a region (province) are calculated. This is a stage referred to as the indexation of regions. Indices serve to assess the value of the indicator of relative environmental validity of developing drainage and irrigation in regions. This assessment is the result of the synthesis of all dimensions of validities, carried out, e.g. based on a multi-criteria dialogue method of ordering variants (in this case: regions). In this synthesis, indices can be divided into those which indicate the environmental need for the development of drainage and irrigation in regions, and those which indicate the environmental possibility for the development of drainage and irrigation.

\section{INDEXING AND SCALING OF THE GIVEN DIMENSION OF ENVIRONMENTAL VALIDITY OF DEVELOPING DRAINAGE AND IRRIGATION IN SUBREGIONS}

The principle that the given dimension of environmental validity of developing drainage and irrigation in the subregions of a given region is indicated by one indicator, which should be developed based on primary indicators inferentially connected with the given dimension of the variable, is assumed. This ought to be an indicator measured on the ordinal scale with a few categories of the given dimension of validity. The number of these categories depends on the researcher. It is advisable for it to be an odd number $(3,5,7, \ldots)$. In the case of five categories, their description may be as follows: climatic (hydrological, soil-water, environmental-ecological) validity of developing drainage and irrigation in the subregions is 1) zero (lack), 2) low, 3) average, 4) high, 5) very high. In this unipolar scale, the lack of validity of developing drainage and irrigation may signify situations in which the development of drainage and irrigation is unfavourable or may even have adverse effects. The knowledge and experience of an expert may serve as the basis for choosing such an indicator. Sometimes, it can also be obtained by formalized methods.

An expert performs the purposeful choice of indicators from a collection of primary indicators of the given dimension of validity of developing drainage and irrigation, or also on the basis of these primary indicators creates a complex measure: index or indicator measured on a specific measurement scale. This measure sums up many primary indicators in a single numerical result, maintaining nearly all details of each of the primary indicators.

An index indicating a given dimension of validity of developing drainage and irrigation can be treated as a sum, possibly with weights, of the results assigned to individual primary indicators inferentially connected with the considered dimension of validity. The totalled indicators ought to be measured on the same measurement scale; indicating such an index in this way may be connected with the necessity of rescaling, based on reducing the scales of all primary indicators taken into account to one type of measurement scale. This should be an ordinal scale.

In addition to the index, there is a possibility to select an indicator measured on a specific, ordinal measurement scale, created based on a few scales of primary indicators. The scale is created by attributing categories (rankings) to some value systems of primary indicators.

Examples of such indicators (indices) measured on specific measurement scales and their rescalings can be found in a work edited by the author [KACA (ed.) 2014]. The indicator chosen among many indicators, rescaled to an indicator of the hydrological dimension of the validity of developing drainage in a subregion, is the average unitary outflow of water in the district [SZYMCZAK 2014]. An indicator of the 
climatic dimension of validity of developing drainage and irrigation in the district (subregion) may be the average multi-annual total precipitation for a given period, or average sum of reference evapotranspiration of plants taken over many years. Based on these two indicators, ŁABĘDZKI [2014] proposed the climatic water balance (CWB) as an index of the climatic validity of developing drainage and irrigation, and rescaled it to an ordinal scale. This is result of the subtraction of average sums of precipitation over many years and average sums of reference evapotranspiration over many years in a subregion for the given period.

An example of a specific ordinal scale is a scale created by OSTROWSKI and TUSIŃSKI [2014] serving to measure the soil-water validity of developing drainage and irrigation in a district based on such primary indicators measured on nominal scales as: production potential, dominant water supply, retention ability, water conductivity and oxygenation conditions of the generalized soil unit which dominates in a district. Another example is the specific ordinal scale of the environmental-ecological validity of developing drainage and irrigation in the district (subregion) created by DEMBEK and OŚWIECIMSKA-PIASKO [2014], enabling the qualification of a district to a given validity category based on the type of legal forms of environmental protection in the district (nominal scale) and share of the area of these forms in the area of the district (ratio scale).

Among the formalized methods, we can include exploratory factor analysis, especially principal component analysis (PCA) (for example described by SHLENS [2014] of components distinguished from primary variables of a continuous nature, e.g. assuming any number values from a certain scope (measured on interval or ratio scales). Primary indicators characterizing the subregions of a given region create a multidimensional space of observations (as many dimensions as there are indicators). In the analysis process, a new observation space is constructed. The space is created by new indicators that are not correlated with each other, being a linear combination of primary indicators. They are referred to as main components. These components (new indicators) explain a certain part of the variability of values of primary indicators describing the given dimension of validity of developing drainage and irrigation in the subregions of a region. Most of this variability is explained by the first component. If this component explains at least the assumed value of variability (e.g 70-80\% of total variation), it can be treated as the sole indicator of the given dimension of the validity of developing drainage and irrigation. Its value is calculated from a formula comprising a linear combination of primary indicators. This indicator will require rescaling, that is the changing over to an ordinal scale. Oftentimes, however, a new indicator obtained in such a way is difficult to sensibly define and interpret, and thus its rescaling may be difficult, at times even impossible.

\section{INDEXATION OF REGIONS ON THE BASIS OF CATEGORIES OF SUBREGIONS}

In the categorization process, each subregion in a region (possibly with the exception of non-agricultural regions) will be assigned to a given $k$-th category on an ordinal scale of the $j$-th dimension of validity of developing drainage and irrigation. Based on these results, we can determine the number of subregions $\left(\sum_{i, j, k}\right)$ in a given $i$-th region, which were assigned to the first, or second, ..., or $k$-th, ..., or $o$-th (the highest) category of a given $j$-th dimension of validity. The frequency $P_{i, j, k}$ (frequency distribution) of the occurrence of subregions in individual categories of a given $j$-th dimension of validity can also be calculated (Tab. 1).

Table 1. Example of table for calculating the relative frequency $P_{i, j, k}$ of subregions in the $i$-th region (province), which belong to subregions in the $k$-th category of the $j$-th dimension of validity of developing drainage and irrigation

\begin{tabular}{|c|c|c|c|c|c|}
\hline \multirow{2}{*}{$\begin{array}{c}\text { Subregion } \\
\text { (district) }\end{array}$} & \multicolumn{5}{|c|}{$\begin{array}{c}\text { The validity of developing drainage and irrigation } \\
\text { in the ordinal scale. Categories: }\end{array}$} \\
\cline { 2 - 6 } & $\begin{array}{c}k=1 \\
\text { lack of }\end{array}$ & $\begin{array}{c}k=2 \\
\text { low }\end{array}$ & $\begin{array}{c}k=3 \\
\text { average }\end{array}$ & $\begin{array}{c}k=4 \\
\text { high }\end{array}$ & $\begin{array}{c}k=5 \\
\text { very high }\end{array}$ \\
\hline 1 & & & 1 & & \\
\hline 2 & & $1^{*}$ & & & \\
\hline$\ldots \ldots$ & & & & & 1 \\
\hline$m$ & & & & & $\sum_{i, j, 5}$ \\
\hline$\sum_{i, j, k}$ & $\sum_{i, j, 1}$ & $\sum_{i, j, 2}$ & $\sum_{i, j, 3}$ & $\sum_{i, j, 4}$ & $\sum_{i, j, j}=$ \\
\hline$P_{i, j, k}$ & $P_{i, j, 1}=$ & $P_{i, j, 2}=$ & $P_{i, j, 3}=$ & $P_{i, j, 4}=$ & $P_{i, j, 5}=$ \\
& $\sum_{i, j, 1} / m$ & $\sum_{i, j, 2} / m$ & $\sum_{i, j, 3} / m$ & $\sum_{i, j, 4} / m$ & $\sum_{i, j, 5} / m$ \\
\hline
\end{tabular}

* For example number 1 signifies that the subregion (e.g. 2) belongs to subregions in the $k$-th (e.g. low, $k=2)$ category of the $j$-th dimension of validity of developing drainage and irrigation; $m=$ number of subregions (after excluding non-agricultural subregions) in the region.

Source: own elaboration.

The distribution of the frequency $P_{i, j, k}$ of subregions in a region characterizes the $j$-th dimension of validity of developing drainage and irrigation in a region. The more subregions with a higher category of this dimension of validity, the higher the validity of developing drainage and irrigation in the region. In the research, we strive for this characteristic to be a continuous variable - assuming numerical values within the range $[0 ; 1]$. In order for this to be the case, individual categories of the ordinal scale organized in increasing order, beginning with the first category $(k=1)$, are assigned a specific number $N_{k}$ of points according for the principle that the higher the number of the category, the more points. Conventionally, $N_{k}=$ $2 k-1$ points can be assigned for the $k$-th category. With these assumptions, it is recommended that the value $W_{i, j}$ of index $W_{j}$ of the validity of developing drainage and irrigation in the $i$-th region according to the $j$-th dimension of validity be calculated according to the following formula:

$$
W_{i, j}=\sum_{k=1}^{o} P_{i, j, k} N_{k}=\sum_{k=1}^{o} P_{i, j, k}(2 k-1)
$$


This formula can be generalized for all regions. Applying matrix calculus, the value $W_{i, j}$ of the index $W_{j}$ of the validity of developing drainage and irrigation in each $(i$-th) region due to the analysed $(j$-th) dimension of validity can be calculated from the formula:

$$
\begin{aligned}
& {\left[\begin{array}{c}
W_{1, j} \\
W_{2, j} \\
\ldots \\
W_{m, j}
\end{array}\right]=\left[\begin{array}{cccc}
P_{1, j, 1} & P_{1, j, 2} & \ldots & P_{1, j, o} \\
P_{2, j, 1} & P_{2, j, 2} & \ldots & P_{2, j, o} \\
\ldots & \ldots & \ldots & \ldots \\
P_{m, j, 1} & P_{m, j, 2} & \ldots & P_{m, j, o}
\end{array}\right] \cdot\left[\begin{array}{c}
N_{1} \\
N_{2} \\
\ldots \\
N_{o}
\end{array}\right]=} \\
& =\left[\begin{array}{cccc}
P_{1, j, 1} & P_{1, j, 2} & \ldots & P_{1, j, o} \\
P_{2, j, 1} & P_{2, j, 2} & \ldots & P_{2, j, o} \\
\ldots & \ldots & \ldots & \ldots \\
P_{m, j, 1} & P_{m, j, 2} & \ldots & P_{m, j, o}
\end{array}\right] \cdot\left[\begin{array}{c}
1 \\
3 \\
\ldots \\
2 o-1
\end{array}\right]
\end{aligned}
$$

where: $i=$ the number of the region $(i=1,2, \ldots, m)$; $j=$ the number of the dimension of the relative environmental validity of developing drainage and irrigation $(j=1,2, \ldots, n) ; k=$ the number of categories in the ordinal scale of the $j$-th dimension of the relative environmental validity of developing drainage and irrigation $(k=1,2, \ldots, o) ; W_{i, j}=$ value of index $W_{j}$ of the relative environmental validity of developing drainage and irrigation in $i$-th region due to the $j$-th dimension of the validity; $P_{i, j, k}=$ percentage of subregions in $k$-th category of the $j$-th dimension of relative environmental validity of developing drainage and irrigation in the $i$-th region; $N_{k}=$ number of points assigned to $k$-th category $\left(N_{k}=2 k-1\right)$.

Indices of the relative validity of developing drainage and irrigation can be subjected to normalization. In econometrics, a few methods can be distinguished. The normalized value of the $i$-th region and $j$-th dimension of validity can be calculated using the zero unitarization method [KUKUŁA 2012]. Due to the fact that the indexes belong to stimulants (assuming a greater value the greater the validity of developing drainage and irrigation), its normalized value can be calculated from the formula:

$$
Z_{i, j}=\frac{W_{i, j}-\min _{i} W_{i, j}}{\max _{i} W_{i, j}-\min _{i} W_{i, j}}
$$

The symbols $\min _{i} W_{i, j}$ and $\max _{i} W_{i, j}$ signify the values of the index of the validity of developing drainage and irrigation in a region with the lowest and the highest validity of developing drainage and irrigation due to the $j$-th dimension (feature).

Such a normalized $Z_{j}$ index can assume values within the range from 0 to $1\left(Z_{j} \in[0 \div 1]\right)$. Regions (provinces) with a value of $Z_{j}=0$ will be regions (provinces) with the same and the lowest, while with $Z_{j}=1-$ regions (provinces) with the same and the highest relative validity of developing drainage and irrigation in the group of regions (provinces) under consideration.
On the basis of this index, regions in the group of regions in regards to the given $j$-th dimension of validity of developing drainage and irrigation, e.g. climatic, soil-water, hydrological and environment-ecological validity, can be compared.

\section{INDEXATION AND SCALING OF THE ENVIRONMENTAL VALIDITY OF DEVELOPING DRAINAGE AND IRRIGATION IN REGIONS}

The basis for indicating the value of the $Q$ indicator of the relative environmental validity of developing drainage and irrigation in the $i$-th region are $Z_{j}$ $(j=1,2, \ldots, n)$ indices, characterizing the given $j$-th dimension of validity of developing drainage and irrigation in this region. The value of this $Q$ indicator can be calculated using the method of the synthesis of normalized $Z_{j}$ indices, based on the relative global model of the decision-maker's preferences.

The problem of establishing the values of the $Q$ indicator based on this model comes down to the problem of ranking regions based on the criteria ( $Z_{j}$ indices) assigned to them and reflecting the ranking of regions in the $Q$ indicator. The value of indicator $Q$ is obtained in the process of ordering regions from the lowest to highest environmental validity of developing drainage and irrigation, resulting from all dimensions $(j=1,2, \ldots, n)$ of environmental validity of developing drainage and irrigation. It should be highlighted that the ranking of provinces is an incorrectly posed problem in mathematical terms, as without additional information, it is difficult to say in which of two regions $-a$ and $x$ - the development of drainage and irrigation is more validated if it is more valid in $a$ than in $x$ in terms of one criterion (one dimension of validity) and less valid in terms of another (second dimension of validity). Solving this problem is connected with the necessity of introducing additional information. This information can come from the decision-maker - these being his/her preferences. The ranking of regions according to a given feature can be carried out using, e.g. the AHP (analytic hierarchy process) method, or ELECTRE III multi-criteria dialogue method of ordering of variants.

The research uses a fragment of the ELECTRE III method for the ordering of variants. This fragment is referred to as the method of calculating the balance of the level of exceedance of one variant (here: region) over another, or in short - the net flow score (NFS) method. The method is described in detail in literature [FIGUEIRA et al. 2013] and programmed. In this method, each index of the $j$-th dimension of validity of developing drainage and irrigation in region $Z_{j}$ (e.g. climatic, soil-water, hydrological, environmentalecological validity) is treated as a criterion. The ranking of regions is carried out based on $Z_{j}$ criteria, using the $S$ exceedance relations, thus a binary relation of $a S x=$ " $a$ is at least as good as $x "$ (due to the $j$-th criterion, the development of drainage and irrigation in 
region $a$ is at least as valid as the development of drainage and irrigation in region $x$ ).

In the case of two regions $a$ and $x$ from the group of regions under consideration, based on the values of these criteria (values of indices), we calculate the compliance indicators $C_{j}(a, x) \in[0,1]$ and noncompliance indicators $D_{j}(a, x) \in[0,1]$ of individual criteria $j(j=1,2, \ldots, n)$ with the hypothesis that the validity of developing drainage and irrigation in region $a$ exceeds the validity of developing drainage and irrigation in region $x$. The definitions of indicators $C_{j}(a, x) \in[0,1]$ and $D_{j}(a, x) \in[0,1]$ have been graphically presented in Figure 1.

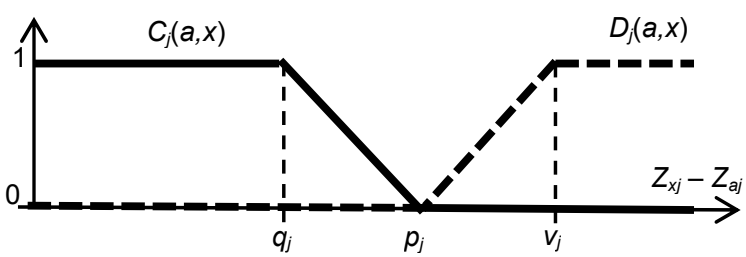

Fig. 1. Graphic presentation of the method of calculating the compliance indicator $C_{j}(a, x)$ and non-compliance indicator $D_{j}(a, x)$, that, due to the $j$-th dimension of validity (criterion) for the development of drainage and irrigation, the validity of developing drainage and irrigation in region $a$ is at least as high as in region $x$; source: own elaboration

As results from Figure 1, the basis for calculations of values of the compliance indicator $C_{j}(a, x)$ and non-compliance indicator $D_{j}(a, x)$ are values of discrimination thresholds: equivalence threshold $q$, preference threshold $p$, and veto threshold $v$, that the validity of developing drainage and irrigation in region $a$ is at least as high as in region $x$. The values of these thresholds for $j$-th criterion of $a$ and $x$ regions are expressed by the formulas:

$$
\begin{aligned}
q_{j} & =\alpha_{q j} \min \left(Z_{a j}, Z_{x j}\right)+\beta_{q j} \\
p_{j} & =\alpha_{p j} \min \left(Z_{a j}, Z_{x j}\right)+\beta_{p j} \\
v_{j} & =\alpha_{v j} \min \left(Z_{a j}, Z_{x j}\right)+\beta_{v j}
\end{aligned}
$$

where: $\min \left(Z_{a j}, Z_{x j}\right)=$ a lower value of the $j$-th dimension of the validity of developing drainage and irrigation in regions $a$ and $x$.

Based on the values of the compliance $C_{j}(a, x) \in$ $[0,1]$ and non-compliance $D_{j}(a, x)$ indicator, the degree of exceedance $\sigma(a, x) \in[0,1]$ of the validity of developing drainage and irrigation in region $a$ over region $x$ is calculated, where $\sigma$ is called the reliability coefficient. Calculations are carried out based on the formula [ROY 1985; SŁOWIŃSKI, ZIELNIEWICZ 2014]:

$$
\sigma(a, x)=\frac{\sum_{j=1}^{n} w_{j} C_{j}(a, x)}{\sum_{j=1}^{n} w_{j}} \Pi_{j \in J}\left[1-D_{j}(a, x)\right]
$$

where: $J$ is a set of all indices (criteria) of the environmental validity of developing drainage and irrigation and $w_{j}(j=1,2, \ldots, n)$ are weights assigned to these indices (criteria).
When indicating weights $w_{j}$ we can assist ourselves with the AHP method developed by SAATY [1980]. In this case, the decision-maker develops a preference matrix of the considered criteria. An example of the formula of such a matrix, in which $n$ preference criteria (dimensions of validity) $Z_{1}, Z_{2}$, $\ldots, Z_{n}$, were distinguished, has been presented in Table 2. Saaty's 9-point scale (from 1 to 9) is used to measure preference. The basic points of this scale are: 1 - equal importance, 3 - moderate importance, 5 strong importance, 7 - very strong importance, 9 extreme importance of one dimension of validity (from the side of the table) over another (from the header of the table). Based on this matrix, the values of weights $w$ can be calculated using, e.g. the calculation possibilities offered by Microsoft Excel.

Table 2. Example of preference matrix of considered preference criteria according to the analytic hierarchy process method

\begin{tabular}{|c|c|c|c|c|}
\hline Criterium & $\mathrm{Z}_{1}$ & $\mathrm{Z}_{2}$ & $\ldots$ & $\mathrm{Z}_{n}$ \\
\hline $\mathrm{Z}_{1}$ & 1 & $3^{*}$ & $\ldots$ & 9 \\
\hline $\mathrm{Z}_{2}$ & $1 / 3$ & 1 & $\ldots$ & 5 \\
\hline$\ldots$ & $\ldots$ & $\ldots$ & $\ldots$ & $\ldots$ \\
\hline $\mathrm{Z}_{n}$ & $1 / 9$ & $1 / 5$ & $\ldots$ & 1 \\
\hline
\end{tabular}

E.g. the number 3 means that the $Z_{1}$ criterion (e.g. climatic) has a moderate advantage over the $Z_{2}$ criterion (e.g. soil-water). Source: own elaboration.

When establishing the values of weights, the division of validity criteria of developing drainage and irrigation may be useful. E.g. when assessing the validity of developing irrigation, the following indices can be included in the criteria expressing the needs for the development of irrigation: climatic and soil-water, while in terms of criteria expressing the possibility for the development of irrigation - the hydrological and environmental-ecological indices. When the considered group of regions is found to under conditions of greater possibilities for the development of drainage and irrigation than needs for development of them, criteria characterizing the needs for development drainage and irrigation should be assigned a higher weight, whilst in the opposite situation, when the needs exceed possibilities, higher weights should be assigned to possibilities.

Values of the $Q$ indicator for the relative validity of the development of drainage and irrigation in any given ( $i$-th) region is the result of the NFS (net flow score) values of the value of the reliability coefficient $\sigma(a, x)$ for each region, at an appropriate NFS cutting level $\lambda$. In this balance, regions are treated as the vertices of a directed graph (Fig. 2). Each edge (directed, that is with an arrow) in this graph is assigned a value equal to the value of the reliability coefficient $\sigma(a, x)$. The edge leaves province $a$ and enters province $x$ when, and only when, $a$ exceeds $x$. In this graph, those edges for which $\sigma \geq \lambda$ are accounted for. The position of region $a$ in the ranking stems from the balance of the sum of $\operatorname{NFS}(a)$ values of edges leaving $a$ and entering $a$, that is [SŁOWIŃSKI, ZIELNIEWICZ 2014]: 


$$
N F S(a)=\sum_{x \in A-a} \sigma(a, x)-\sum_{x \in A-a} \sigma(x, a) ; \quad \sigma \geq \lambda
$$

where: $A=$ a set of all regions.

The higher the value of $N F S(a)$, the higher the placement of the region.



Fig. 2. Graph of net flow score NFS(a) balance of values of reliability coefficients $\sigma(a, x)$ - that the validity of the development of drainage and irrigation in region $a$ is higher than as compared to the validity in the remaining regions, and reliability coefficients $\sigma(x, a)$, that the validity of the development of drainage and irrigation in regions outside of region $a$ is higher as compared to the validity in region $a$, at $N F S$ cutting level $\lambda$; source: own elaboration

The NFS $(a)$ indicator, as an indicator of the relative environmental validity of the development of drainage and irrigation in region $a$, is the difference of the sum of reliability coefficients $\sigma(a, x)>\lambda$, that the validity of developing drainage and irrigation in region $a$ is higher as compared to the validity in the remaining considered regions, and sum of reliability coefficients $\sigma(x, a)>\lambda$, that the validity of developing drainage and irrigation in all considered regions besides region $a$ is higher as compared to the validity in region $a$.

Removing the arcs with a low level of exceedance, that is with a value of $\sigma(a, x)<\lambda$, is to prevent undesirable equivalence of the sum of small degrees of exceedance with one markedly high level of exceedance. The values of $\operatorname{NFS}(a)$ can be negative and positive. In extreme cases, $\operatorname{NFS}(a)$ can take on values $-(m-1)$ or $+(m-1)(m-$ number of regions $)$. In the first case, region $a$ will be characterized by the lowest (in relations to the remaining regions) validity of developing drainage and irrigation, while in the second case - the greatest validity:

Calculated $\operatorname{NFS}(a)$ values can be subjected to normalization according to the formula:

$$
Q_{i}=\frac{N F S_{i}+m-1}{(m-1) m} 100 \%
$$

It is easy to demonstrate that, because $\Sigma N F S_{i}=0$, then $\Sigma Q_{i}=100 \%$. This means that $Q$ expresses the estimation of the validity of developing drainage and irrigation in the $i$-th region, which together with the estimations of the validity of developing drainage and irrigation in the remaining $(m-1)$ regions belonging to the considered group of $m$ regions is equal to $100 \%$. In other words, $Q$ means the involvement of the region in the environmental validity of developing drainage and irrigation in the considered group of regions. The validity of developing drainage and irrigation in the group of regions is $100 \%$.

In the case that the regions in the group are not homogeneous, i.e. in some of them outweighs the needs (possibilities) over the possibilities (needs) the development of drainage and irrigation, calculating the value of $Q$ can be according to the formula:

$$
Q_{i}=\frac{\min \left(Q_{i}^{\prime} ; Q_{i}^{\prime \prime}\right)}{\sum_{1}^{m} \min \left(Q_{i}^{\prime} ; Q_{i}^{\prime \prime}\right)}
$$

where: $Q_{i}$ ' and $Q_{i}{ }^{\prime \prime}=$ values of the $Q$ for $i$-th region according to the NFS method and Equation (7), calculated respectively when the criteria (weights $w$ ) of the needs exceed the criteria concerning possibilities of development of drainage or irrigation and vice versa the criteria (weights $w$ ) of the possibilities exceed the criteria concerning the needs.

\section{ENVIRONMENTAL VALIDITY OF DEVELOPING IRRIGATION IN THE PROVINCES OF POLAND (EXAMPLE)}

In the research on determining the environmental validity of developing irrigation on the scale of Polish provinces, the values of indicators of the validity of developing irrigation in the districts of the given province, publicized under the editorship of the author [KACA 2014], were used. The climatic and soil-water need for the development of irrigation and the hydrological and environmental-ecological possibility of its realization were accounted for.

In the description of the climatic validity (need) of developing drainage and irrigation in a subregion, the average climatic water balance (CWB) over many years, as the difference between the atmospheric precipitation and reference evapotranspiration in the district during the period of plant vegetation, proposed by ŁABĘDZKI [2014], was used, while for the indicator of the hydrological validity (possibility) of irrigation - the indicator of the available water outflow proposed by SZYMCZAK [2014]. These indicators (climatic, hydrological) are continuous variables measured on a ratio scale, expressed respectively in $\mathrm{mm}$ and $\mathrm{dm}^{3} \cdot \mathrm{s}^{-1} \cdot \mathrm{km}^{-2}$. The mentioned authors changed these scales into ordinal scales of the need/ possibility for the development of irrigation and carried out the qualification of districts in the provinces into individual categories.

The group of indicators of the soil-water dimension of the validity (need) of developing irrigation in the subregion was proposed by OSTROWSKI and TUSIŃSKI [2014]. These were: the productive potential, 
the dominant water supply, retention ability, water conductivity and the oxygenation conditions of the dominant generalized soil unit in the district. Each of these indicators is measured on a nominal scale with two or three distinguished categories. On the basis of appropriately selected layouts of categories of these scales, the mentioned author created a specific ordinal scale in which he distinguished a few categories of soil-water validity (need) of developing irrigation in the district. Based on this scale, he calculated the number of districts in the province belonging to the specified categories of validity of developing irrigation.

Two indicators proposed by DEMBEK and OśWIECIMSKA-PIASKO [2014] were used to describe the dimension of the environmental-ecological validity (possibility) of developing drainage and irrigation in the district. This was a type of legal form of environmental protection in the district and the share $(\%)$ of the area of these forms in the area of the district. The values of the first indicator were measured on a nominal scale with four categories (four types of environmental protection), while the second - on a ratio scale. Based on properly selected layouts of categories and values of these scales, the mentioned author created a specific ordinal scale in which he distinguished a few categories of environmental-ecological validity (possibility) for developing drainage and irrigation in a district. Based on these scales, he specified the number of districts in the provinces belonging to the specified categories.

Based on these data, Table 1 and Equations (2) and (3), calculations of the indices of the environmental need for (climatic and soil-water) and environmental possibility (hydrological and environmental-ecological) of developing irrigation in the provinces were carried out. The results of these calculations have been presented in Table 3 .
It was confirmed that there is a significant $(p<$ 0.05 ) correlation between the index of the climatic $C V$ and hydrological $H V$, as well as between the index of climatic $C V$ and soil-water $S W V$ relative validity of developing irrigation in a province (Tab. 4). Between the remaining indices, as could be expected, these relationships are statistically insignificant. The statistically significant relationship between $\mathrm{CV}$ and $\mathrm{HV}$ means that, in provinces with a high need for irrigation, the possibilities of its realization are limited due to insufficient availability of water. Such a relationship is known in practice and described in scientific literature. On the other hand, the relationship between $C V$ and $S W V$ may be connected with the influence of the climate on soil-formation processes. The obtained values of the correlation coefficient can be the basis for stating that the indices of the validity of developing drainage and irrigation in the provinces under consideration have been selected reliably and accurately.

In connection with these dependencies and data in Table 3, it can be stated that, due to climatic circumstances, among the Polish provinces the following ones (listed in descending order) are characterized by the highest validity (need) of developing irrigation: Wielkopolskie $(C V=1.00)$, Lubuskie $(C V=0.96)$ and Kujawsko-Pomorskie $(C V=0.83)$, whereas the lowest: Małopolskie $(C V=0.00)$, Podkarpackie $(C V=$ $0.09)$ and Sląskie $(C V=0.10)$. The first group of provinces contains those with the lowest available resources of flowing surface waters, thus with the lowest hydrological validity (possibility) of developing irrigation, whereas in the second group - provinces with the highest hydrological validity (possibility) of irrigation. Where soil-water criteria are concerned, those provinces with the highest validity of developing irrigation include: Śląskie, Opolskie and Podlaskie, while from the environmental-ecological point

Table 3. Values of indices of the climatic, soil-water, hydrological and environmental-ecological validity of developing irrigation in the individual provinces

\begin{tabular}{|c|c|c|c|c|c|c|c|}
\hline \multicolumn{4}{|c|}{ Indices of the need for developing irrigation } & \multicolumn{4}{|c|}{ Indices of the possibility of developing irrigation } \\
\hline \multicolumn{2}{|l|}{ climatic index $C V$} & \multicolumn{2}{|c|}{ soil-water index $S W V$} & \multicolumn{2}{|c|}{ hydrological index $H V$} & \multicolumn{2}{|c|}{$\begin{array}{c}\text { environmental-ecological index } \\
E E V\end{array}$} \\
\hline province & value & province & value & province & value & province & value \\
\hline Małopolskie & 0.00 & Lubuskie & 0.00 & Kujawsko-pomorskie & 0.00 & Lubuskie & 0.00 \\
\hline Podkarpackie & 0.09 & Wielkopolskie & 0.18 & Lubelskie & 0.00 & Podlaskie & 0.01 \\
\hline Śląskie & 0.10 & Pomorskie & 0.50 & Lubuskie & 0.00 & Warmińsko-Mazurskie & 0.02 \\
\hline Pomorskie & 0.34 & Zachodniopomorskie & 0.53 & Łódzkie & 0.00 & Podkarpackie & 0.13 \\
\hline Świętokrzyskie & 0.35 & Łódzkie & 0.53 & Mazowieckie & 0.00 & Zachodniopomorskie & 0.20 \\
\hline Dolnośląskie & 0.38 & Świętokrzyskie & 0.64 & Podlaskie & 0.00 & Małopolskie & 0.22 \\
\hline Warmińsko-Mazurskie & 0.40 & Podkarpackie & 0.66 & Wielkopolskie & 0.02 & Świętokrzyskie & 0.24 \\
\hline Lubelskie & 0.56 & Kujawsko-Pomorskie & 0.68 & Pomorskie & 0.31 & Pomorskie & 0.28 \\
\hline Łódzkie & 0.60 & Lubelskie & 0.71 & Dolnośląskie & 0.32 & Lubelskie & 0.55 \\
\hline Opolskie & 0.62 & \begin{tabular}{|l|} 
Dolnośląskie \\
\end{tabular} & 0.72 & \begin{tabular}{|l|} 
Świętokrzyskie \\
\end{tabular} & 0.34 & Mazowieckie & 0.59 \\
\hline Podlaskie & 0.62 & Małopolskie & 0.72 & Opolskie & 0.39 & Dolnośląskie & 0.63 \\
\hline Zachodniopomorskie & 0.70 & Warmińsko-Mazurskie & 0.75 & Zachodniopomorskie & 0.45 & Wielkopolskie & 0.65 \\
\hline Mazowieckie & 0.76 & Mazowieckie & 0.82 & Warmińsko-Mazurskie & 0.79 & Śląskie & 0.68 \\
\hline Kujawsko-Pomorskie & 0.83 & Podlaskie & 0.91 & Śląskie & 0.81 & Kujawsko-pomorskie & 0.71 \\
\hline Lubuskie & 0.96 & Opolskie & 0.94 & Podkarpackie & 0.88 & Opolskie & 0.79 \\
\hline Wielkopolskie & 1.00 & Śląskie & 1.00 & Małopolskie & 1.00 & Łódzkie & 1.00 \\
\hline
\end{tabular}

Source: own elaboration based on data acc. to KACA and OSTROWSKI [2014] 
Table 4. Matrix of correlations between indices of a given dimension of validity of developing irrigation in provinces

\begin{tabular}{|c|c|c|c|c|}
\hline Index & $C V$ & $H V$ & $S W V$ & $E E V$ \\
\hline$C V$ & 1 & & & \\
\hline$H V$ & $\mathbf{- 0 . 8 2 0 4}$ & 1 & & \\
\hline$S W V$ & $\mathbf{- 0 . 5 0 5 9}$ & 0.3561 & 1 & \\
\hline$E E V$ & 0.1884 & -0.3154 & 0.1934 & 1 \\
\hline
\end{tabular}

The coefficients of correlation which are statistically significant at $p<0.05$ are in bold.

Source: own elaboration.

of view, these are: Łódzkie, Opolskie and Kujawsko-Pomorskie. These are provinces characterized by a relatively low share of areas with specific types of environmental protection.

The synthesis of these indices according to the NFS method (fragment of the ELECTRE III method) was carried out two times, obtaining values of the NFS indicator (in the research, MCDA Toolkit computer software was used, operating on an EXCEL base and developed at the Institute of Computing Science of the Poznań University of Technology).

The first synthesis pertained mainly to indices of the need for developing irrigation (climatic index and soil-water index), the second - indices of the possibilities of developing irrigation (hydrological index and environmental-ecological index). On the basis of these values and Equation (8), the values of the $Q$ ' indicator of the environmental need, $Q$ " indicator of the environmental possibility and $Q$ indicator of the validity of developing irrigation in the provinces were assessed (Tab. 5).

The calculations of $N F S_{i}$ were carried out excluding the veto threshold, at a cutting level of $\lambda=0.5$.

Calculating the values of the $Q$ ' and $Q$ " indicators of the validity of developing irrigation was carried out on the bases of indices of the: climatic, soil-water, hydrological and environmental-ecological validity of developing irrigation (Tab. 3), using weights according to Table 6 . The values of these weights were indicated using the AHP method, following the assumption that, under Polish conditions, in part of the provinces the environmental possibilities of developing irrigation exceed the environmental needs, and in the remaining provinces the environmental needs for developing irrigation exceed the environmental possibilities. In the first case (the first synthesis), the environmental validity of developing irrigation is determined by needs and, to a lesser extent, possibilities. As a result, criteria characterizing the needs for the development of irrigation were assigned higher weights as compared to the weights of criteria characterizing the environmental possibilities of irrigation. In the second case (the second synthesis), - the environmental validity of developing irrigation is determined by possibilities and, to a lesser extent, needs. In these case - criteria characterizing the possibilities were assigned higher weights as compared to the weights of criteria characterizing the environmental needs for irrigation. For example, in the first case (the first synthesis) it was assumed (Tab. 6), that the climatic validity of developing irrigation ( $\mathrm{CV}$ indicator) has a less than moderate (2) advantage over the soilwater ( $S W V$ indicator) validity of developing irrigation, strong (5) advantage over the hydrological validity ( $H V$ indicator) and very strong (7) advantage over the ecological-environmental validity ( $E E V$ indicator). It was also assumed that the soil-water validity $(S W V)$ has a moderate (3) and strong (5) advantage over the hydrological $(H V)$ and environmental-ecological $(E E V)$ validities, respectively, while the hydrological validity $(H V)$ has a moderate (3) advantage over the environmental-ecological validity $(E E V)$.

The values of thresholds: equivalents $q$ and preferences $p$ (the veto threshold $v$ was not accounted for in the calculations) were calculated from Equation (4)

Table 5. Ranking of provinces and values of indicators of the environmental validity (need, possibility) of developing irrigation

\begin{tabular}{|c|c|c|c|c|c|}
\hline \multicolumn{2}{|c|}{ Need for developing irrigation } & \multicolumn{2}{|c|}{ Possibility of developing irrigation } & \multicolumn{2}{|c|}{ Validity of developing irrigation } \\
\hline province & $Q^{\prime}, \%$ & province & $Q ", \%$ & province & $Q, \%$ \\
\hline Małopolskie & 1.8 & Lubuskie & 2.3 & Małopolskie & 2.8 \\
\hline Podkarpackie & 2.1 & Łódzkie & 2.8 & Podkarpackie & 3.3 \\
\hline Pomorskie & 3.2 & Wielkopolskie & 2.9 & Lubuskie & 3.6 \\
\hline Śląskie & 3.6 & Lubelskie & 3.2 & Łódzkie & 4.3 \\
\hline Świętokrzyskie & 4.2 & Kujawsko-Pomorskie & 3.6 & Wielkopolskie & 4.5 \\
\hline Dolnośląskie & 4.6 & Podlaskie & 4.1 & Lubelskie & 4.9 \\
\hline Warmińsko-Mazurskie & 5.0 & Mazowieckie & 4.4 & Pomorskie & 5.0 \\
\hline Łódzkie & 6.0 & Pomorskie & 5.6 & Śląskie & 5.6 \\
\hline Lubelskie & 6.5 & Świętokrzyskie & 6.5 & Kujawsko-Pomorskie & 5.6 \\
\hline Podlaskie & 7.5 & Dolnośląskie & 6.7 & Podlaskie & 6.4 \\
\hline Zachodniopomorskie & 7.9 & Zachodniopomorskie & 7.8 & Świętokrzyskie & 6.4 \\
\hline Opolskie & 8.7 & Opolskie & 9.1 & Mazowieckie & 6.8 \\
\hline Lubuskie & 9.4 & Podkarpackie & 9.6 & Dolnośląskie & 7.2 \\
\hline Mazowieckie & 9.6 & Warmińsko-Mazurskie & 9.7 & Warmińsko-Mazurskie & 7.8 \\
\hline Kujawsko-Pomorskie & 9.8 & Śląskie & 10.5 & Zachodniopomorskie & 12.1 \\
\hline Wielkopolskie & 10.0 & Małopolskie & 11.1 & Opolskie & 13.5 \\
\hline Total & 100.0 & & 100.0 & & 100.0 \\
\hline
\end{tabular}

Source: own elaboration. 
Table 6. Matrix of advantages of considered preference criteria - indices of the: climatic $(C V)$, soil-water $(S W V)$, hydrological $(H V)$ and environmental-ecological (EEV) validity of developing irrigation in the provinces, as well as weights calculated according to AHP method

Calculation of $Q_{i}{ }^{\prime}$ values (the first synthesis)
\begin{tabular}{|l|c|c|c|c|c|}
\hline Indicator & $C V$ & $S W V$ & $H V$ & $E E V$ & $\begin{array}{c}\text { Weight } \\
w\end{array}$ \\
\hline$C V$ & 1 & 2 & 5 & 7 & 0.52 \\
\hline$S W V$ & 0.50 & 1 & 3 & 5 & 0.30 \\
\hline$H V$ & 0.20 & 0.33 & 1 & 3 & 0.12 \\
\hline$E E V$ & 0.14 & 0.20 & $0,33$. & 1 & 0.06 \\
\hline
\end{tabular}

Calculation of $Q_{i}$ " values (the second synthesis)

\begin{tabular}{|l|c|c|c|c|c|}
\hline Indicator & $H V$ & $S W V$ & $C V$ & $E E V$ & $\begin{array}{c}\text { Weight } \\
w\end{array}$ \\
\hline$H V$ & 1 & 2 & 5 & 7 & 0.52 \\
\hline$S W V$ & 0.50 & 1 & 3 & 5 & 0.30 \\
\hline$C V$ & 0.20 & 0.33 & 1 & 3 & 0.12 \\
\hline$E E V$ & 0.14 & 0.20 & $0,33$. & 1 & 0.06 \\
\hline
\end{tabular}

Source: own elaboration.

assuming $\alpha_{p j}=0, \alpha_{q j}=0 \beta_{p j}=0.05, \beta_{q j}=0.10$. This means (Fig. 1) that, due to the given criterion, two provinces characterized by the values of this criterion, differing from each other by a value lower than $\beta_{p j}=0.05$, were considered as equal in regards to the validity of developing irrigation according to the compared criterion, those for which the difference did not exceed the value $\beta_{q j}=0.10-$ as differing to a specified degree, while those for which the difference exceeded the value $\beta_{q j}=0.10$ - as differing between each other.

Accounting for the climatic and soil-water relative needs and hydrological and environmentalecological relative possibilities (Tab. 5), it should be stated that Opolskie and Zachodniopomorskie provinces, for which the indicator of the validity of developing irrigation is approx. $Q \approx 12-13 \%$ are characterized by the highest environmental validity of developing irrigation, whereas Małopolskie, Podkarpackie and Lubuskie provinces are characterized by the lowest, i.e. $Q \approx 3 \%$.

\section{CONCLUSIONS}

In the research, an attempt was made to develop a methodology for assessing (quantifying) the relative environmental validity of developing drainage and irrigation in a region (province), and thus a specific feature of the region, treated as objectified and quantified view (standpoint, belief) often described in the developmental strategies for the regions, especially in regional (provincial) plans for the development of drainage and irrigation. This feature is treated as a theoretical construct - a directly unobservable (hidden) variable of the region, in which four dimensions are distinguished, i.e.: climatic, hydrological, soilwater and environmental-ecological dimension.

The methodology consists of two parts. The first pertains to the climatic, hydrological, soil-water and environmental-ecological quantification of the relative environmental validity of developing drainage and irrigation in the regions (provinces), while the second - to the synthesis of these partial validities into one indicator - the relative environmental validity of developing drainage and irrigation in a region (province). When carrying out the first part, indicators characterizing the partial validities of developing drainage and irrigation in subregions (districts) are used, whereas in the second - the net flow score method, comprising a fragment of the ELECTRE III multi-criteria dialogue method of ordering of variants.

Based on the proposed method, as an example, the values of climatic, hydrological, soil-water and environmental-ecological indices, as well as the relative environmental validity of developing irrigation in the provinces of Poland were indicated.

\section{REFERENCES}

BABBIE E. 2008. Podstawy badań społecznych [Basis for social studies]. Warszawa. PWN. ISBN 978-83-10$15155-3$ pp. 577.

BAC S., KoźMiŃSKi Cz., RojeK M. 1993. Agrometeorologia [Agrometeorology]. Warszawa. PWN. ISBN 83-0111114-3 pp. 249.

Dembek W., Oświecimska-Piasko Z. 2014. Przyrodniczoekologiczne uwarunkowania rozwoju melioracji. W: Uwarunkowania rozwoju melioracji wodnych w Polsce [Biological and ecological determinants of reclamation development. In: Determinants of reclamation development in Poland]. Ed. E. Kaca. Woda-Środowisko-Obszary Wiejskie. Rozprawy naukowe i monografie. Nr 37. Falenty. Wydaw. ITP p. 113-127.

Figueira J., Greco S., RoY B., SŁowiŃSKi R. 2013. An overview of ELECTRE method and their recent extension. Journal of Multi-Criteria Decision Analysis. Vol. 20 p. 61-85.

GRABARCZYK S. 1987. Efekty, potrzeby i możliwości nawodnień deszczownianych w różnych regionach kraju [Effects, needs and possibilities of sprinkler irrigation in different regions of the country]. Zeszyty Problemowe Postępów Nauk Rolniczych. Z. 314 p. 49-64.

KACA E. 2015a. Podstawy metodyczne obliczeń w programowaniu rozwoju melioracji wodnych. Aspekty rzeczowo-kosztowe [The methodological basis for calculations in programming of the land reclamation development. Material and cost aspects]. Woda-Środowisko-Obszary Wiejskie. Rozprawy naukowe i monografie. $\mathrm{Nr} 41$. Falenty. Wydaw. ITP. ISBN 978-83-65426-00-0 pp. 105.

KACA E. 2015b. Średnio- i długookresowe programy rozwoju melioracji wodnych w skali kraju i województw [Average- and long-term programmes of the development of drainage and irrigation on the national and provincial scale]. Falenty. Wydaw. ITP. ISBN 978-8365426-03-1 pp. 159.

KACA E. (ed.) 2014. Uwarunkowania rozwoju melioracji wodnych w Polsce [Determinants of the reclamation development in Poland]. Woda-Środowisko-Obszary Wiejskie. Rozprawy naukowe i monografie. Nr 37. Falenty. Wydaw. ITP. ISBN 978-83-62416-84-4 pp. 195.

KACA E., OSTROWSKI J. 2014. Uwarunkowania i zasadność rozwoju melioracji. W: Uwarunkowania rozwoju melioracji $\mathrm{w}$ Polsce [Determinants and advisability of reclamation development. In: Determinants of reclamation development in Poland]. Ed. E. Kaca. Woda-Środowi- 
sko-Obszary Wiejskie. Rozprawy naukowe i monografie. Nr 37. Falenty. Wydaw. ITP p. 167-191.

KUKUŁA K. 2012. Propozycja budowy rankingu obiektów z wykorzystaniem cech ilościowych oraz jakościowych [Proposal of constructing rankings of objects using quantitative as well as qualitative features]. Metody Ilościowe w Badaniach Ekonomicznych. T. 13. Z. 1 p. 516.

ŁABĘDZKI L. 2006. Susze rolnicze. Zarys problematyki oraz metody monitorowania i kwalifikacji [Agricultural droughts. Outline of the problem and methods of monitoring and qualification]. Woda-Środowisko-Obszary Wiejskie. Rozprawy naukowe i monografie. Nr 17. Falenty. IMUZ pp. 107.

ŁABĘDZKI L. 2014. Klimatyczne uwarunkowania rozwoju melioracji. W: Uwarunkowania rozwoju melioracji w Polsce [Climatic determinants of reclamation development. In: Determinants of reclamation development in Poland]. Ed. E. Kaca. Woda-Środowisko-Obszary Wiejskie. Rozprawy naukowe i monografie. Nr 37. Falenty. Wydaw. ITP p. 35-52.

MiodUSZEWSKI W. 2015. Uwarunkowania społeczne i przyrodnicze rozwoju melioracji w skali kraju i województw. Załącznik B. W: Średnio- i długookresowe programy rozwoju melioracji wodnych w skali kraju i województw [Social and environmental determinants of the development of drainage and irrigation on a national and provincial scale. Attachment B. In: Mediumand long-term programmes for the development of drainage and irrigation on a national and provincial scale]. Ed. E. Kaca. Falenty. Wydaw. ITP p. 127-159.

NowAK S. 2007. Metodologia badań społecznych [Methodology of social studies]. Warszawa. PWN. ISBN 97883-01-14999-4 pp. 495.

OKRUSZKO H. 1976. Zasady rozpoznawania i podziału gleb hydrogenicznych z punktu widzenia potrzeb melioracji. $\mathrm{W}$ : Materiały pomocnicze do badań gleboznawczych przy projektowaniu melioracji [Guidelines for identifying and dividing hydrogenic soils regarding drainage and irrigation needs. In: Auxiliary materials for soil research in reclamation design]. Biblioteczka Wiadomości IMUZ. Nr 52. Warszawa. PWRiL p. 7-54.
OSTROMĘCKI J. 1971. Odwodnienia w melioracjach użytków zielonych [Drainage of grassland]. Warszawa. SGGW pp. 161.

OSTROMĘCKI J. 1973. Podstawy melioracji nawadniających [Basics of irrigation works]. Warszawa. PWN pp. 450.

OSTROWSKI J., TUSIŃSKI E. 2014. Glebowo-wodne uwarunkowania rozwoju melioracji. W: Uwarunkowania rozwoju melioracji w Polsce [Soil-water determinants of reclamation development. In: Determinants of reclamation development in Poland]. Ed. E. Kaca. Woda-Środowisko-Obszary Wiejskie. Rozprawy naukowe i monografie. Nr 37. Falenty. Wydaw. ITP p. 86-112.

RoY B. 1985. Wielokryterialne wspomaganie decyzji [Multi-criteria decision-making support]. Translation B. Słowiński. Warszawa. WNT. ISBN 83-204-1119-X pp. 282.

SAATY T.L. 1980. The analytic hierarchy process: planning, priority setting, resource allocation. New York-London. Mcgraw-Hill International Book Co. ISBN 0070543712 pp. 287.

SHLENS J. 2014. A tutorial on principal component analysis. Google Research Mountain View, CA 94043 (Dated: April 7, 2014; Version 3.02). From Wikipedia.

SŁOWIŃSKI R., ZIELNIEWICZ P. 2014. Metody wielokryterialnego wspomagania decyzji - uzasadnienie wyboru i opis metody ELECTRE III/IV [Methods of multicriteria decision-making - Justifying the selection of and description of ELECTRE III/IV method]. Poznań. Instytut Informatyki Politechniki Poznańskiej. Typescript pp. 85.

SZYMCZAK T. 2014. Hydrologiczne uwarunkowania rozwoju melioracji. W: Uwarunkowania rozwoju melioracji w Polsce [Hydrological determinants of reclamation development. In: Determinats of reclamation development in Poland]. Ed. E. Kaca. Woda-Środowisko-Obszary Wiejskie. Rozprawy naukowe i monografie. $\mathrm{Nr}$ 37. Falenty. Wydaw. ITP p. 53-85.

WĘZIAK-BIAŁOWOLSKA D. 2011. Operacjonalizacja i skalowanie w ilościowych badaniach społecznych [Operationalization and scaling in quantitative social studies]. Zeszyty Naukowe - Instytut Statystyki i Demografii SGH. No. 16 pp. 49.

ZAWADZKi S. (ed.) 1999. Gleboznawstwo [Soil science]. Warszawa. PWRiL. ISBN 8309017030 pp. 559.

\section{Edmund KACA}

\section{Metodyka szacowania względnej przyrodniczej zasadności rozwoju odwodnień i nawodnień w skali regionów}

\section{STRESZCZENIE}

Przedmiotem pracy jest specyficzna cecha regionu w grupie regionów, którą jest względna przyrodnicza zasadność rozwoju w nim odwodnień i nawodnień. Względna, gdyż odnoszona do przyrodniczej zasadności rozwoju melioracji w regionach należących do wyróżnionej grupy regionów.

Problemem pracy jest pytanie o metodykę szacowania (kwantyfikacji) względnej przyrodniczej zasadności rozwoju melioracji w regionie (województwie). Opracowanie takiej metodyki i zaprezentowanie przykładu jej zastosowania stanowi cel pracy.

Metodyka składa się z dwóch części. Pierwsza dotyczy rodzajowej, np. klimatycznej, glebowo-wodnej, hydrologicznej itp., kwantyfikacji względnej przyrodniczej zasadności rozwoju melioracji w regionach (województwach), druga zaś - syntezy tych cząstkowych rodzajowych zasadności w jeden wskaźnik - względną przyrodniczą zasadność rozwoju melioracji w regionie (województwie). W realizacji pierwszej części wykorzystuje się 
wskaźniki charakteryzujące cząstkowe zasadności rozwoju melioracji w subregionach (powiatach), w drugiej zaś - fragment wielokryterialnej dialogowej metody porządkowania wariantów ELECTRE III.

Na podstawie zaproponowanej metodyki sklasyfikowano województwa w Polsce. Klasyfikacji dokonano na podstawie takich rodzajowych zasadności rozwoju melioracji, jak: zasadność klimatyczna, glebowo-wodna, hydrologiczna i przyrodniczo-ekologiczna. Według tej klasyfikacji największą przyrodniczą zasadnością rozwoju nawodnień charakteryzuje się województwo opolskie, najmniejszą zaś - małopolskie.

Wstępne analizy potwierdziły trafność i rzetelność proponowanej metodyki szacowania względnej przyrodniczej zasadności rozwoju nawodnień w województwach.

Słowa kluczowe: metoda AHP, metoda ELECTRE III, nawodnienia, odwodnienia, ranking regionów, rozwój melioracji rolnych 